Article

\title{
Sea Buckthorn and Rosehip Oils with Chokeberry Extract to Prevent Hypercholesterolemia in Mice Caused by a High-Fat Diet In Vivo
}

\author{
Lubov Tereshchuk ${ }^{1}$, Kseniya Starovoytova ${ }^{1}$, Olga Babich ${ }^{2,3}$ (), Lyubov Dyshlyuk ${ }^{4}$,

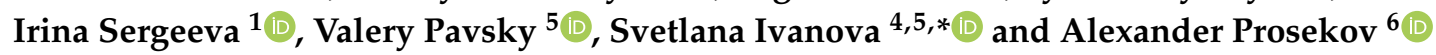 \\ 1 Vegetable Food Technology Department, Kemerovo State University, Krasnaya Street 6, \\ 650043 Kemerovo, Russia; terechuk_1@mail.ru (L.T.); centol@mail.ru (K.S.); sergeeva.76@list.ru (I.S.) \\ 2 Institute of Living Systems, Immanuel Kant Baltic Federal University, A. Nevskogo Street 14, \\ 236016 Kaliningrad, Russia; olich.43@mail.ru \\ 3 Single Center of Collective Use, Innovation Park, Immanuel Kant Baltic Federal University, \\ A. Nevskogo Street 14, 236016 Kaliningrad, Russia \\ 4 Natural Nutraceutical Biotesting Laboratory, Kemerovo State University, Krasnaya Street 6, \\ 650043 Kemerovo, Russia; soldatovals1984@mail.ru \\ 5 Department of General Mathematics and Informatics, Kemerovo State University, Krasnaya Street, 6, \\ 650043 Kemerovo, Russia; pavva46@mail.ru \\ 6 Laboratory of Biocatalysis, Kemerovo State University, Krasnaya Street 6, 650043 Kemerovo, Russia; \\ a.prosekov@inbox.ru \\ * Correspondence: pavvm2000@mail.ru; Tel.: +7-384-239-6832
}

Received: 5 September 2020; Accepted: 23 September 2020; Published: 25 September 2020

\begin{abstract}
Dietary supplementation based on sea buckthorn and rosehip oils with added chokeberry extract was studied. We added the dietary supplement to the feed mixtures for laboratory animals. The possible toxicological effects and hypocholesterolemic, hepatoprotective activity of the dietary supplement in vivo were studied. After the observation period (6 weeks), no significant changes were found in the mass of organs and blood serum of laboratory animals $(p>0.05)$. However, there was a decrease in hypercholesterolemic indicators. Regular consumption of sea buckthorn and rosehip oils with added chokeberry extract (dietary supplement "ESB-1") by laboratory animals inhibited the activity of liver enzymes and increased the antioxidant activity of blood serum (after the subcutaneous injection of sunflower oil/oil solution of carbon tetrachloride) but was not sufficient to bring them to physiological standards. The hypocholesterolemic and antioxidant properties of our dietary supplement already allow us to consider it a component of functional food products or a dietary supplement base. However, the full range of its biologically active properties, including the hepatoprotective function and regulation of metabolic disorders, has not been studied yet, which sets the direction of further research in vivo models and clinical practice to confirm its effectiveness in humans.
\end{abstract}

Keywords: dietary supplement; sea buckthorn and rosehip oils; chokeberry; antioxidant activity; hypolipidemic; hepatoprotective effects

\section{Introduction}

In addition to oncological diseases, cardiovascular diseases, hepatitis, and diabetes are the main ones causing death or disability. Such diseases can often be prevented by maintaining a healthy lifestyle and sticking to a healthy diet [1-3]. Plant food components with antioxidant properties, especially the ones with phenolic compounds, are of particular interest. Phenolic-enriched diets 
have been found to help prevent a wide range of diseases and slow down the aging process [4-6]. In addition, hepatoprotective, antiproliferative and anti-obesity effects of phenolic compounds have been reported [7-9]. A high content of polyunsaturated fatty acids (PUFA), mainly vegetable oil and nuts, is a key component of a healthy diet to prevent heart diseases [10,11].

The creation of products that combine the effects of PUFA and antioxidant substances, while preserving natural benefits, is both interesting and relevant for scientists, doctors, and manufacturers. Bright-colored fruits are known to be rich in antioxidant substances [12-14]. If these fruits were also rich in polyunsaturated fatty acids, like those in fish oil [15], they would be perfect healthy products.

Sea buckthorn berries can be considered such a product, as their oil has antioxidant characteristics and the benefits of fatty acids. Sea buckthorn berries contain vitamins $\left(A, B_{1}, B_{2}, B_{3}, B_{6}, C, E, K\right.$, etc.), as well as organic acids (up to $2.5 \%$ ), quercetin, flavonoids, macro- and microelements, fatty oil ( $9 \%$ in the pulp, $12 \%$ in the kernels), which consists of triacylglycerols with saturated and unsaturated fatty acids (palmitooleic, oleic, linoleic, linolenic).

Previously, it was proved that sea buckthorn berries and their derivatives possess a wide range of beneficial characteristics: anti-inflammatory, antitumor, antioxidant, antiatherosclerotic, cholesterol-lowering, hypoglycemic, hepatoprotective, and antidiabetic effects [16-18]. There are reports that sea buckthorn products are safe foods with no serious side effects, except for an increase in blood glucose levels in rats at a significant rate of consumption ( $>100 \mathrm{mg} / \mathrm{kg} / \mathrm{day})$ of berries per day [19-21]. Both sea buckthorn berries and their derivatives are often considered as the basis of therapeutic and/or preventive food products [22,23].

Sea buckthorn oil extracted from both seeds and pulp is the main source of PUFA [24,25]: mature seeds contain $8-20 \%$ of oil, dried fruit pulp (pulp and peel)—about $20-25 \%$, and fruit residue contains about $15-20 \%$ of oil after juice extraction $[24,26]$. These oils have a high concentration of lipophilic components, primarily unsaturated fatty acids in the form of triglycerides, phytosterols, and vitamins $\mathrm{A}$ and $\mathrm{E}[25,27-29]$; they have a positive effect on human health, especially on the cardiovascular system $[26,30]$.

Another promising raw material for functional products is rosehip, the fruit of which contains a large amount of vitamins (C, B2, A, K, P, and E) and fatty oil [31-33]. The oil content in rosehip seeds varies from 5 to $18 \% \mathrm{wt}$. and consists of a significant amount of unsaturated fatty acids [34,35]. Other significant groups of biologically active rosehip compounds are galactolipids and unsaturated fatty acids [36,37]. The fatty acid composition of rosehip oil is represented by stearic (up to $4 \%$ ), palmitic (5\%), oleic (up to $20 \%$ ), linoleic (up to $50 \%$ ), and linolenic acids (up to $40 \%$ ). Lycopene makes rosehip and its products beneficial for the prevention of cardiovascular diseases and cancer [33,37-42]. Rosehip fruits have anti-inflammatory, antioxidant, antiproliferative, and antidiabetic properties [31,43-48].

Chokeberry (Aronia melanocarpa) is a rich source of polyphenols (including anthocyanins, flavonols, flavanols, proanthocyanidins, and phenolic acids), which determine the high biological activity of its berries $[49,50]$. Chokeberry fruits and their derivative products contain vitamins P, A, E, PP, and B-vitamins, microelements, amygdalin glycoside, and have great health potential, as they reduce the risk of metabolic syndrome development.

It has been confirmed (in vitro and in vivo) that chokeberry has beneficial effects on various diseases (dyslipidemia, hypertension, obesity, glucose metabolism disorders, pro-inflammatory conditions, and the risk of thrombosis) [51,52].

Mixtures of medicinal plants have been traditionally used since ancient times [53,54]. Mixtures may contain leaves, roots, shoots of plants, as well as their seeds, berries, fruit. It is important to follow the rules of preparation of mixtures, so that plant components reinforce each other's actions and are safe to consume. Similar rules are applied to the development of dietary supplements. The aim of the study was to evaluate the effect of sea buckthorn oil, rosehip oil, and chokeberry extract combined on the manifestation of hypercholesterolemia in mice due to the predominance of fat in the diet. 


\section{Materials and Methods}

\subsection{Materials}

"ESB-1" dietary supplementation (the patent application is under consideration at Rospatent http: //www1.fips.ru) was the object of this study-a microemulsion (containing $100 \mathrm{~g}$ of $90.0 \%$ fat, PUFA $\omega-3$ not less than $25.3 \%$, PUFA $\omega-6$ not less than $25.3 \%$, omega-9 not less than $12.0 \%$, essential phospholipids not less than $10.0 \%$, $\alpha$-tocopherol $17.9 \%$, $\beta$-carotene $0.1 \%$, rutin $3.3 \%$ ). The supplement was obtained from the composition of vegetable oils of different fatty acid groups (linseed, rapeseed, sunflower, taken at the ratio of 50:20:30) using the fruit raw material derivate products (sea buckthorn (Hippóphae rhamnoides) ) and rosehip (Rosa Cinnamomea) at the ratio of 1:1, pre-dried to a moisture content of $12 \%$ and crushed to powder). Vegetable phospholipids (soy lecithin, 93\% phospholipid content, Art life, Tomsk, Russia) and water extract of chokeberry (Arónia melanocárpa) were added to the mixture that was then thoroughly mixed. The content of active components in the "ESB-1" dietary supplement is shown in Table 1.

Table 1. Active substances in the "ESB-1" dietary supplement (per one $2.0 \mathrm{~g}$ capsule).

\begin{tabular}{cc}
\hline Active Substance & Content \\
\hline PUFA $\omega-3$, not less & $380 \mathrm{mg}$ \\
including $\alpha$-linolenic acid, not less than & $175 \mathrm{mg}$ \\
PUFA $\omega$-6, not less than & $380 \mathrm{mg}$ \\
including linoleic acid, not less than & $265 \mathrm{~m}$ \\
$\gamma$-linolenic acid, not less than & $110 \mathrm{mg}$ \\
$\omega-9$ (oleic acid), not less than & $180 \mathrm{mg}$ \\
essential phospholipids & $150 \mathrm{mg}$ \\
$\alpha$-tocopherol & $400 \mathrm{IU}$ \\
$\beta$-carotene & $2 \mathrm{mg}$ \\
rutin & $50 \mathrm{mg}$ \\
\hline
\end{tabular}

ESB-Extract of Siberian Berries.

\subsection{Feed Mixtures}

Feed mixtures were made up of components according to the recipes (Table 2), as described in our previous study $[55,56]$. Weighing was performed on laboratory scales (accuracy $0.01 \mathrm{~g}$ ). Saccharose, AIN-93-VX vitamin mix, L-cysteine, choline bitartrate and corn starch were stirred in a mixer until a homogeneous mixture was obtained for $15 \mathrm{~min}$ at a rotation speed of $60 \pm 5 \mathrm{rpm}$. Next, casein and a mixture of mineral salts AIN-93M were added, stirred for another $10 \mathrm{~min}$, then corn starch dextrinate was added to the mixture and stirred for another $15 \mathrm{~min}$. In the homogenizer, 2-tert-butylhydroquinone in soy oil and a ghee solution were added to the resulting mixture. According to the recipe, soybean oil (mixture No. 1) and cholesterol (mixture No. 2 and No. 3) were homogenized for 10 min. At the last stage, the "ESB 1" dietary supplement (mixture No. 3 and No. 7) was added and the components of the mixtures were homogenized for $10 \mathrm{~min}$. The prepared mixtures were stored in sealed plastic containers for no more than 5 days at a temperature of $(4 \pm 2){ }^{\circ} \mathrm{C}$. 
Table 2. Feed mixture recipes ( $\mathrm{g} / \mathrm{kg}$ of feed).

\begin{tabular}{cccccccc}
\hline \multirow{2}{*}{ Ingredients } & \multicolumn{7}{c}{ Feed Mixture } \\
\cline { 2 - 8 } & No. 1 & No. 2 & No. 3 & No. 4 & No. 5 & No. 6 & No. 7 \\
\hline Corn starch & 510.7 & 509.7 & 508.6 & 506.5 & 456.5 & 458.7 & 454.5 \\
Dextrinate corn starch & 155.0 & 155.0 & 155.0 & 155.0 & 155.0 & 155.0 & 155.0 \\
Casein & 145.0 & 145.0 & 145.0 & 145.0 & 145.0 & 145.0 & 145.0 \\
Saccharose & 90.0 & 90.0 & 90.0 & 90.0 & 90.0 & 90.0 & 90.0 \\
Soybean oil & 50.0 & 50.0 & 50.0 & 50.0 & 10.0 & 10.0 & 10.0 \\
$\quad$ Ghee & - & - & - & - & 90.0 & 90.0 & 90.0 \\
AIN-93M (mixture of mineral & 35.0 & 35.0 & 35.0 & 35.0 & 35.0 & 35.0 & 35.0 \\
$\quad$ salts) & 10.0 & 10.0 & 10.0 & 10.0 & 10.0 & 10.0 & 10.0 \\
AIN-93-VX (vitamin mix) & 1.8 & 1.8 & 1.8 & 1.8 & 1.8 & 1.8 & 1.8 \\
L-cysteine & 2.5 & 2.5 & 2.5 & 2.5 & 2.5 & 2.5 & 2.5 \\
Choline bitartrate & - & - & - & - & - & 2.0 & 2.0 \\
Cholesterol & - & 1.0 & 2.1 & 4.2 & 4.2 & - & 4.2 \\
“ESB-1" dietary supplement & 8.0 & 8.0 & 8.0 & 8.0 & 8.0 & 8.0 & 8.0 \\
2-tert-butylhydroquinone in soy & oil, mg & & & & & & \\
\hline
\end{tabular}

AIN-93-VX, Vitamin Mix and AIN-93M, Mixture of Mineral Salts (MP Biomedical LLC, Santa Ana, CA, USA) are components of the recommended diet for rats and mice in scientific research.

\subsection{Experimental Animals}

Male white rats (Wistar strain, age — 4 months, weight—not less than $300 \pm 1 \mathrm{~g}$ ) were purchased from the Center for Genetic Resources of Laboratory Animals of the Institute of Cytology and Genetics the Siberian Branch of the Russian Academy of Sciences (Novosibirsk, Russia). The rats were given free access to the feed (granulated complete feed, BioPro, Russia) and drinking water. Prior to the experiment, the animals were quarantined for at least 2 weeks, as described in our previous study $[55,56]$. All rats were placed in polycarbonate cages (5 in each cage; at a temperature of $22 \pm 2{ }^{\circ} \mathrm{C}$; relative humidity of at least $60 \%$ ). Each cage had drinkers, steel label holders, steel feed dividers, steel latticed lids with a feed recess, removable prefilters and HEPA (High Efficiency Particulate Air) air filters. The daily cycle of animals was $12 \mathrm{~h}$ of light and $12 \mathrm{~h}$ of darkness. The study was conducted in accordance with the Declaration of Helsinki; The BioEthical Committee of the Research Institute of Biotechnology of the Kemerovo State University approved the experimental protocol (Project identification code 1118/23.11.2018).

\subsection{Experimental Design}

Three days before the experiment (after 14 days of quarantine), all animals (each rat weighing up to $200 \mathrm{~g}$ ) were randomly divided into groups. The control and experimental groups included 15 animals each. The animals were placed in individual ventilated cages. The air renewal rate in the system was not less than $15 \mathrm{~m}^{3} / \mathrm{h}$. The cages were placed in a rack-shelf.

During the study, the following parameters were maintained (air temperature $-22 \pm 2{ }^{\circ} \mathrm{C}$, relative humidity—at least $60 \%$, air velocity in the system-at least $15 \mathrm{~m}^{3} / \mathrm{h}$, and the daily cycle of light and darkness $-12 \mathrm{~h}$ ). The animals were allowed drinking water ad libitum. Straw bedding, food and drinking water were changed daily. For animals weighing under $350 \mathrm{~g}$, the daily portion of food weighed $25 \mathrm{~g}$ (basic nutrients) or $30 \mathrm{~g}$ for animals weighing over $350 \mathrm{~g}$. At least once a week, experimental animals were weighed on laboratory scales (absolute error $\pm 0.1 \mathrm{~g}$ ) in a $5 \mathrm{dm}^{3}$ plastic cup. All experiments on rats were conducted in the morning (in accordance with ethical principles for conducting painful experiments on animals and with the current guidelines for the care of laboratory animals).

During the entire study period, all animals were under constant observation. The experimental groups, the feeding regime, and the manipulations performed are presented in Table 3. 
Table 3. Experimental design.

\begin{tabular}{cccc}
\hline Group & Number of Animals & Subcutaneous Injection & Diet \\
\hline I & 15 & - & No. 1 \\
II & 15 & - & No. 2 \\
III & 15 & - & No. 3 \\
IV & 15 & - & No. 4 \\
V & 15 & - & No. 5 \\
VI & 15 & - & No. 6 \\
VII & 15 & Sterile refined and deodorized & No. 7 \\
VIII & 15 & sunflower oil 1 mL/kg of weight & No. 1 \\
& 15 & Oil solution of carbon tetrachloride, & No. 1 \\
IX & 15 & 1 mL/kg of weight & No. 4 \\
& & Oil solution of carbon tetrachloride, & 1 mL/kg of weight \\
X & & &
\end{tabular}

The animals were observed daily for 6 weeks. Animal behavior, their general condition, the nature and intensity of motor activity, the color of mucous membranes, skin, fur condition, the volume of feed and water consumed, tail position, mass of organs, biochemical and hematological parameters of blood, and blood serum (clinical signs of intoxication) were recorded during the intravital phase, as described in our previous study $[55,56]$. Twelve hours before the end, feed leftovers were removed from the cages. Animals from experimental groups were euthanized with carbon dioxide (feed rate $-3.5 \mathrm{dm}^{3} / \mathrm{min}$; gas anesthesia system for laboratory animals, RWD Life Science, Shenzhen, Guangdong, P.R. China) depending on the animal's body weight for 3 to $5 \mathrm{~min}$. After the absence of respiratory movements was visually confirmed, the animals were removed from the euthanasia chamber.

Blood sampling $\left(5 \mathrm{~cm}^{3}\right)$ was carried out using sterile syringes from the heart cavity after the 6-week experiment came to an end. Animals were put under anesthesia with ether vapors and fixed on the dissecting table with their belly up. Palpation on the left side of the chest determined the cardiac impulse position. The syringe needle was inserted $5 \mathrm{~mm}$ horizontally to the sternum to the point of cardiac impulse. After the euthanasia, organs (heart, lungs, liver, kidneys, spleen, thymus, adrenal glands) were taken for weighing.

Animals from groups I-IV (Table 3) were tested for toxicological characteristics of "ESB-1" dietary supplement. Animals from groups VI and VII) were tested for the presence of hypocholesterolemic characteristics in "ESB-1" dietary supplement.

At the beginning of the experiment, group I animals were subjected to euthanasia with organ and blood sampling. Animals from groups VIII-X were manipulated as described in Table 3. Sterile refined, deodorized sunflower oil or an oil solution of carbon tetrachloride was injected into the withers subcutaneously with a $1.0 \mathrm{~cm}^{3}$ syringe at a dose of $1 \mathrm{~mL} / \mathrm{kg}$. In 24,48 and $72 \mathrm{~h}$ after the administration of oil or oil solution, five animals of each group were euthanized with carbon dioxide and the biomaterial was taken for analysis.

\subsection{Evaluation of Biochemical Parameters of Blood Serum}

Using the solid-phase spectrophotometric method [57], the levels of cholesterol, triglycerides, high- and low-density lipoproteins (HDL and LDL), and unesterified fatty acids (UFA) were determined in serum samples using "Cholesterol" (BioSystems S.A., Barcelona, Spain), "Triglycerides" (BioSystems S.A., Barcelona, Spain), Cholesterol HDL Direct (BioSystems S.A., Barcelona, Spain), and 96-well Serum/Plasma Fatty Acid kit (ZenBio Inc., Morrisville, NC, USA) kits while following the manufacturers' recommendations. The absorption of the solution was measured with a spectrophotometer $(1 \mathrm{~cm}$ cuvette) at a wavelength of $500 \mathrm{~nm}$, for UFA a wavelength of $540 \mathrm{~nm}$ and for lipoprotein wavelengths of 600 and $700 \mathrm{~nm}$. 
The Berthelot enzymatic colorimetric method was used to determine the urea concentration in the serum with a commercial kit (BioSystems S.A., Barcelona, Spain). The absorption of light produced by indiphenol is proportional to the urea content in the sample at a wavelength of $500-560 \mathrm{~nm}$.

A spectrophotometer with a thermostatic compartment (wavelength $340 \mathrm{~nm}$, temperature $37^{\circ} \mathrm{C}$, quartz cuvettes $1 \mathrm{~cm}$ ) was used to determine the activity of alanine aminotransferase (ALT) and aspartate aminotransferase (AST) in the samples of serum as described in our previous study $[55,56]$ with Alanine aminotransferase ALT/GPT (BioSystems S.A., Barcelona, Spain) and Aspartate aminotransferase AST/GOT (BioSystems S.A., Barcelona, Spain) kits, following the manufacturer's instructions.

The RAPID N (Cube protein nitrogen analyzer is an analyzer for fast and absolutely safe determination of nitrogen (protein) in food) Cube protein nitrogen analyzer and Dumas method were used to determine total protein content in the blood serum. The Dumas method is based on measuring the thermal conductivity of molecular nitrogen produced after combustion of the sample in an oxygen atmosphere at a temperature of about $1000{ }^{\circ} \mathrm{C}$, followed by a reduction of all the resulting nitrogen oxides with a reducing agent (copper).

Capillary electrophoresis (Kapel-105, Lumeks, Russia) was used to determine globulins and albumins in the serum.

The Popper method based on the Jaffe reaction with a commercial kit (BioSystems S.A., Barcelona, Spain) determined creatinine in the blood serum.

Bilirubin in the serum of laboratory animals was determined by measuring bilirubin absorption using the spectrophotometric method (BioSystems S.A., Barcelona, Spain) at 440-460 nm.

Automated hematological analyzer ADVIA 60 (Siemens, Germany) was used to determine hematological parameters (hemoglobin level; number of red blood cells, white blood cells, platelets; hematocrit; average concentration of hemoglobin in red blood cells) in the serum samples.

\subsection{Testing of Hepatoprotective Properties}

Spectrophotometrically, using Lactate dehydrogenase (LDH), Aspartate aminotransferase AST/GOT, and Alanine aminotransferase ALT/GPT (BioSystems S.A., Barcelona, Spain) commercial kits and following the manufacturer's recommendations, the activity of LDH, AST, and ALT was determined in the serum. Optical density of the solutions was determined using a spectrophotometer with a thermostatic compartment $\left(1-\mathrm{cm}\right.$ quartz cuvettes, temperature $37^{\circ} \mathrm{C}$, wavelength of $\left.340 \mathrm{~nm}\right)$.

In serum and liver homogenates, the concentration of TBA-reactive products was determined using a non-absorbing microplate spectrophotometer (wavelength 535 and $572 \mathrm{~nm}$ ); it was expressed in the equivalent of the concentration of malondialdehyde (MDA) [58,59].

\subsection{Testing of Antioxidant Activity}

Kinetic spectrophotometry (wavelength $734 \mathrm{~nm}$, data collected at intervals of $1 \mathrm{~min}$, duration $40 \mathrm{~min}$ ) was used to determine the antioxidant activity of the dietary supplement to reduce the concentration of ABTS cationic radical in the blood serum; it was expressed through the equivalent concentration of the water-soluble analogue of vitamin E-Trolox [60].

Values determining the ability to absorb oxygen radicals were determined by the equation:

ORAC (oxygen radicals absorption capacity) $=\mathrm{X} \cdot \mathrm{K} \cdot\left(\mathrm{S}_{\text {sample }}-\mathrm{S}_{\text {blank }}\right) /\left(\mathrm{S}_{\text {trolox }}-\mathrm{S}_{\text {blank }}\right)$,

where $\mathrm{X}$ is the volume of the sample $(\mu), \mathrm{K}$ is the dilution coefficient of the sample, and $\mathrm{S}$ is the area under the fluorescence decay curve of the sample.

\subsection{Statistical Analysis}

Each experiment with the biomaterials was repeated three times. The data in the tables were expressed as means \pm standard error of mean (SEM), and the data in the figures were represented as means \pm standard error (SE). The homogeneity of the sampling effects was checked using Student's 
$t$-test. The data were subjected to analysis of variance (ANOVA) using Statistica 10.0 (StatSoft Inc., 2007, Tulsa, Ok, USA). Differences between means were considered significant when the confidence interval was smaller than $5 \%(p \leq 0.05)$.

\section{Results}

The potential of plant-based components and the production of functional products by processing vegetables and fruits is well known and has been used by us multiple times [55,61-65]. Our works $[56,66,67]$ present the results of studying bio-functional properties in vitro and the potential to increase physical endurance with help of pine nut processing products, including oil, in vivo. We went further and developed a dietary supplement based on sea buckthorn and rosehip oil. To enhance its biological activity, chokeberry extract was added.

This work presents the results of studying the potential of using our dietary supplement as a component of functional nutrition in vivo. There were no deaths or signs of intoxication in the in vivo study during the follow-up period, including acute toxicity during the first $24 \mathrm{~h}$ after the dietary supplement intake. There were no significant differences $(p>0.05)$ in body weight and height, skin and fur between the control group and the rats that were fed our dietary supplement. Under the influence of the dietary supplement, the behavior of animals and their intake of food did not change. After 6 weeks (Figures 1-3), serum levels of laboratory animals remained unchanged regardless of their diet ( $p>0.05$, by LSD (LSD method-Least Square Difference method of statistics) post-hoc test), except for cholesterol and triglycerides. Their high content depended on the diet. Animals of group's I-IV did not receive either animal fat or cholesterol in their diet, and animals of groups V-VII had animal fats (ghee) in combination with or without cholesterol in their diet. There were no significant differences in the weight of organs between the groups of animals. In all animal groups, the organ weight was as follows: heart $1.25 \pm 0.06 \mathrm{~g}$, lung $1.46 \pm 0.06 \mathrm{~g}$, liver $9.56 \pm 0.47 \mathrm{~g}$, kidney $3.12 \pm 0.15 \mathrm{~g}$, spleen $0.93 \pm 0.05$, thymus $0.42 \pm 0.02$, adrenal glands $0.11 \pm 0.01 \mathrm{~g}$. Toxicological studies [68] of the dietary supplement based on sea buckthorn and rosehip oils with added chokeberry extract confirmed its safety, since no toxic effect on the body of laboratory animals has been established.

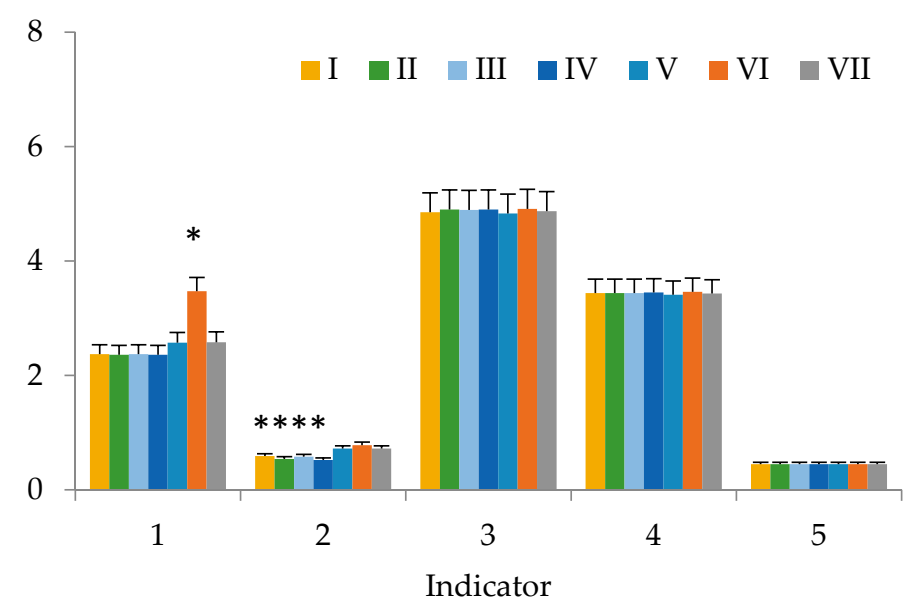

Figure 1. Biochemical and hematological indices of blood of animals from groups I-VII: 1-Cholesterol, $\mathrm{mmol} / \mathrm{L} ; 2$-Triglycerides, mmol/L; 3-Bilirubin, $\mu \mathrm{mol} / \mathrm{L} ; 4$-Number of leukocytes, $\mathrm{g} / \mathrm{L} ; 5$-Hematocrit, $\mathrm{L} / \mathrm{L}$ (bars in graphs indicate the SE of 15 replicates). Values with «*» do differ significantly $(p>0.05)$. 


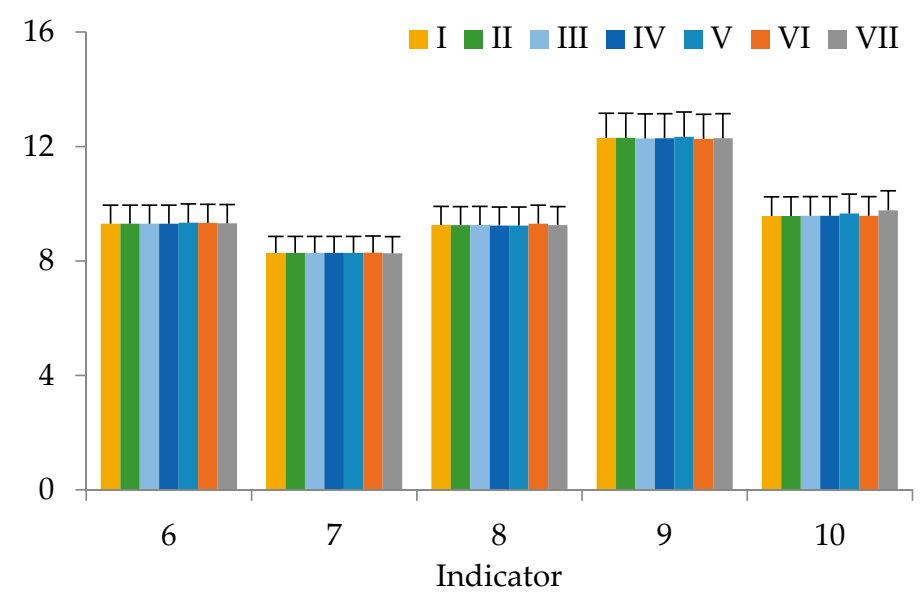

Figure 2. Biochemical and hematological indices of blood of animals from groups I-VII: 6-Urea, mmol/L; 7-ALT, U/L; 8-AST, U/L; 9-Globulins, g/L; 10-Red blood cell count, g/L; (bars in graphs indicate the $\mathrm{SE}$ of 15 replicates).

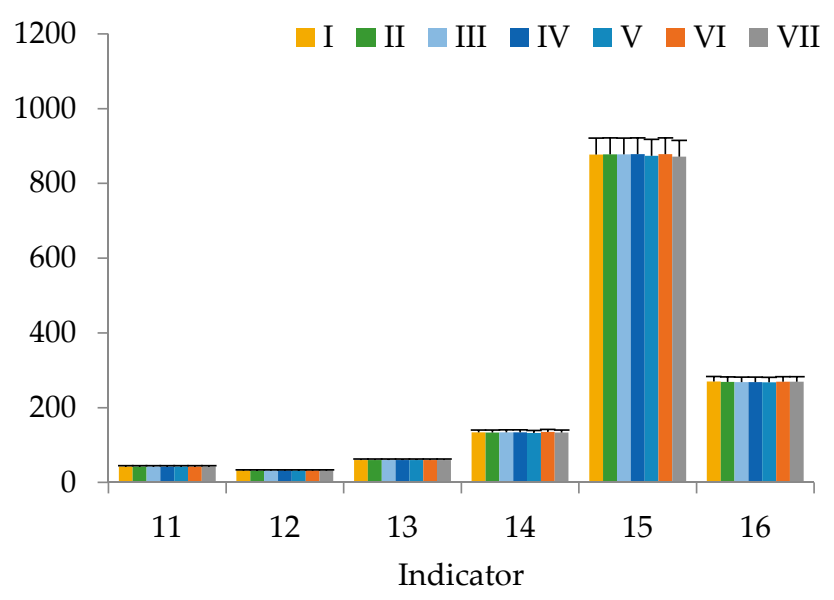

Figure 3. Biochemical and hematological indices of blood of animals from groups I-VII: 11-Total protein, g/L; 12-Albumin, g/L; 13-Creatinine, $\mu \mathrm{mol} / \mathrm{L} ; 14-$ Hemoglobin level, g/L; 15—Platelet count, $\mathrm{g} / \mathrm{L} ; 16$ - Average concentration hemoglobin in the erythrocyte, $\mathrm{g} / \mathrm{L}$ (bars in graphs indicate the SE of 15 replicates).

The results of the study of blood samples of laboratory animals from groups I-VII show that, after 6 weeks, there were statistical significant increases in cholesterol and triglycerides in the blood serum. The triglyceride content (Figure 1) was statistically determined by the presence or absence of animal fats (ghee) in the diet. Cholesterol and triglyceride values in groups of animals taking a diet with a significant amount of animal fats (mixture No. 6) were significantly different from the control animals ( $p=0.899$ and $p=0.921$, respectively). For laboratory animals consuming mixture No. 7 with a significant content of animal fats, no significant differences from the control group in regard to cholesterol were revealed, just like with mixture No. 6.

Comparing these indicators in animals from Groups VI-VII, whose diets differed only in the presence or absence of a dietary supplement based on sea buckthorn and rosehip oils with added chokeberry extract, the positive effect of this supplement is observed. Apparently, the biologically active components of sea buckthorn and rosehip oils with added chokeberry extract in the supplement activated the gastrointestinal system function, leading to the splitting and processing of additional cholesterol administered into the body of laboratory animals according to the consumed formula.

Changes in the activity of liver enzyme indicators in the serum of laboratory animals from groups VIII-X after the administration of oil or an oil solution of carbon tetrachloride (Table 4) demonstrate 
significant liver damage. This is evidenced by an increase in the content of AST and ALT in the serum of the animals from the considered groups as compared to the control: from 1.2 to 3.5 , from 2.2 to 5.9 , 2.3 to 7.8 times and from 1.3 to 2.8 , from 2.7 to 5.7 , from 3.0 to 5.7 times, respectively, 24, 48 and $72 \mathrm{~h}$ after subcutaneous administration (Table 1). Animals from group IX had the highest content of liver enzymes; the introduction of oil solution of carbon tetrachloride without any intake of our dietary supplement led to the highest liver damage. Adding sea buckthorn and rosehip oils and chokeberry extract to the diet (group X) did not lead to AST and ALT values comparable to those in the control group but significantly minimized the negative impact of subcutaneous administration of solution of carbon tetrachloride on the liver.

Table 4. Indicators of oxidative processes in the liver and blood serum antioxidant activity of laboratory animals.

\begin{tabular}{|c|c|c|c|c|}
\hline \multirow{2}{*}{$\begin{array}{l}\text { Duration of Incubation, } \\
\text { after Subcutaneous } \\
\text { Administration of Oil/Oil } \\
\text { Solution of Carbon } \\
\text { Tetrachloride, h }\end{array}$} & \multicolumn{4}{|c|}{ Groups } \\
\hline & I & VIII & IX & $X$ \\
\hline \multicolumn{5}{|c|}{ Lactate dehydrogenase (U/L) } \\
\hline Control & $208.92 \pm 1.92^{\mathrm{a}}$ & - & - & - \\
\hline 24 & - & $234.67 \pm 1.94^{\mathrm{a}}$ & $463.98 \pm 3.02^{\mathrm{a}}$ & $265.47 \pm 1.92^{\mathrm{a}}$ \\
\hline 48 & - & $243.02 \pm 1.93^{\mathrm{a}}$ & $508.57 \pm 2.97^{\mathrm{a}}$ & $304.31 \pm 1.92^{\mathrm{a}}$ \\
\hline 72 & - & $266.04 \pm 2.00^{a}$ & $586.12 \pm 3.17^{a}$ & $316.22 \pm 1.92^{\mathrm{a}}$ \\
\hline \multicolumn{5}{|c|}{ Aspartate aminotransferase (U/L) } \\
\hline Control & $9.24 \pm 0.17^{\mathrm{a}}$ & - & - & - \\
\hline 24 & - & $11.03 \pm 0.32^{\mathrm{a}}$ & $32.76 \pm 0.63^{a}$ & $15.06 \pm 0.18^{a}$ \\
\hline 48 & - & $41.97 \pm 0.34^{b}$ & $54.22 \pm 0.38^{b}$ & $20.04 \pm 0.23^{b}$ \\
\hline 72 & - & $21.34 \pm 0.24^{b}$ & $72.18 \pm 0.51^{b}$ & $23.11 \pm 0.22^{b}$ \\
\hline \multicolumn{5}{|c|}{ Alanine aminotransferase (U/L) } \\
\hline Control & $8.36 \pm 0.21^{a}$ & - & - & - \\
\hline 24 & - & $10.51 \pm 0.32^{\mathrm{a}}$ & $23.18 \pm 0.42^{b}$ & $12.23 \pm 0.72^{a}$ \\
\hline 48 & - & $47.46 \pm 0.54 \mathrm{~b}$ & $42.44 \pm 0.38^{b}$ & $22.46 \pm 0.78^{b}$ \\
\hline 72 & - & $25.84 \pm 0.57^{b}$ & $47.36 \pm 0.45^{b}$ & $25.47 \pm 0.45^{b}$ \\
\hline \multicolumn{5}{|c|}{ TBA-reactive products (umol/dm ${ }^{3}$ MDA) } \\
\hline Control & $3.31 \pm 0.16^{\mathrm{a}}$ & - & - & - \\
\hline 24 & - & $3.95 \pm 0.21^{b}$ & $4.23 \pm 0.21^{b}$ & $3.27 \pm 0.17^{\mathrm{a}}$ \\
\hline 48 & - & $6.86 \pm 0.33^{b}$ & $8.46 \pm 0.43^{b}$ & $3.43 \pm 0.17^{\mathrm{a}}$ \\
\hline 72 & - & $6.92 \pm 0.34^{b}$ & $11.18 \pm 0.57^{b}$ & $3.66 \pm 0.17^{\mathrm{a}}$ \\
\hline \multicolumn{5}{|c|}{ Homogenates of liver (nmol MDA/g) } \\
\hline Control & $41.7 \pm 4.2^{\mathrm{a}}$ & - & - & - \\
\hline 24 & - & $50.0 \pm 5.1^{b}$ & $53.4 \pm 5.4^{b}$ & $40.8 \pm 4.1^{\mathrm{a}}$ \\
\hline 48 & - & $58.7 \pm 5.8^{b}$ & $65.0 \pm 6.6^{b}$ & $44.3 \pm 4.3^{\mathrm{a}}$ \\
\hline 72 & - & $63.7 \pm 6.3^{b}$ & $78.7 \pm 7.9^{b}$ & $47.1 \pm 4.6^{\mathrm{a}}$ \\
\hline \multicolumn{5}{|c|}{ Antioxidant capacity (umol TE/umol) } \\
\hline Control & $5.65 \pm 0.56^{\mathrm{a}}$ & - & - & - \\
\hline 24 & - & $4.56 \pm 0.55^{\mathrm{a}}$ & $3.13 \pm 0.32^{b}$ & $5.75 \pm 0.57^{\mathrm{a}}$ \\
\hline 48 & - & $4.11 \pm 0.51^{\mathrm{a}}$ & $2.75 \pm 0.27^{b}$ & $5.36 \pm 0.54^{\mathrm{a}}$ \\
\hline 72 & - & $3.99 \pm 0.51^{\mathrm{a}}$ & $2.00 \pm 0.22 b$ & $5.10 \pm 0.50^{\mathrm{a}}$ \\
\hline
\end{tabular}

The data are expressed as mean \pm SE $(n=15)$. Values followed by different letters in a line have considerable differences $(p>0.05)$ by LSD post-hoc test. I group-without subcutaneous administration; feed mixture No. 1; VIII group—subcutaneous oil administration; feed mixture No. 1; IX group—subcutaneous oil solution administration; feed mixture No. 1; X group—subcutaneous oil solution administration; feed mixture No. 4. MDA: malondialdehyde; LSD method - Least Square Difference method of statistics. TE: tocopherol equivalent. 
The performed manipulations have led to liver damage, which is out of question (groups VIII-IX). There were some positive changes in the animals from group VIII in $72 \mathrm{~h}$ after the manipulation; however, in this case, it seems that a longer rehabilitation period is needed to restore liver function. For group IX animals, negative effects accumulated throughout the entire observation period $(72 \mathrm{~h})$, which, it seems, cannot be neutralized by the body's own protective forces. The results of group $X$ indicate that the intake of sea buckthorn oil, rosehip oil, and chokeberry extract during the preparatory period allowed creating an internal protective barrier. It is possible that an increase in the rehabilitation period (more than $72 \mathrm{~h}$ ) or an increase in the dosage of the consumed biologically active complex could provide complete recovery of liver functions, although additional research is required.

Antioxidant activity (Table 3) of the laboratory animal serum was dramatically reduced by the oil solution of carbon tetrachloride administered subcutaneously. Vegetable oil administration also led to a decrease in this indicator, but not so dramatically. The decrease in antioxidant activity in $72 \mathrm{~h}$ after administration reached $65 \%$ and $30 \%$ for oil solution of carbon tetrachloride and vegetable oil, respectively. For the group that took the dietary supplement with sea buckthorn and rosehip oils with added chokeberry extract, the decrease in antioxidant activity did not exceed $11 \%$, almost corresponding to the indicators of the control group.

\section{Discussion}

We do not know any works that would study the properties of dietary supplements or products with similar formulations. There are works that study properties of the key components of our supplement separately. Sea buckthorn oil is known to have anti-inflammatory properties [69] and promote tissue regeneration [70]. Rosehip fruit extracts have been proven to have antioxidant, anti-inflammatory, immunomodulatory, anti-tumor, cardioprotective, antidiabetic, neuroprotective, and antimicrobial properties [71]. However, the hypolipidemic, hepatoprotective properties of sea buckthorn, rosehip oils and chokeberry extract, especially in the composition of bioactive supplements, have not been studied enough.

Our results are consistent with the results of [72]. For 60 days, sea buckthorn oil was added to the feed of white rabbits. One group was a control group, one group was fed sea buckthorn oil only, one - cholesterol diet ( $1 \mathrm{~mL} /$ day) only, and one more-cholesterol diet and sea buckthorn oil (after 30 days of high-cholesterol diet received sea buckthorn oil $1 \mathrm{~mL} /$ day for the next 30 days). Feeding sea buckthorn oil to common rabbits for 18 days resulted in a significant decrease in cholesterol, LDL, atherogenic index, and LDL/HDL ratio in the blood plasma. The cholesterol diet in rabbits decreased the acetylcholine-induced vasorelaxant activity, but was restored to normal values by the administration of sea buckthorn seed oil. The consumption of sea buckthorn oil after a high-cholesterol diet reduced both cholesterol and triglycerides, but did not lead to results of a pre-cholesterol diet. In our study, a similar effect is achieved in less time, apparently due to the synergistic effect of sea buckthorn and rosehip oils with the addition of chokeberry extract.

Hsu et al. [73] studied the protective effect of sea buckthorn seed oil on liver damage in mice caused by carbon tetrachloride $\left(\mathrm{CCl}_{4}\right)$. It was found out that oral supplementation of $0.26 \mathrm{mg} / \mathrm{kg}$ to $2.6 \mathrm{mg} / \mathrm{kg}$ of sea buckthorn seed oil for eight weeks reduced the increased levels of ALT, AST, alkaline phosphatase (ALP), triglyceride (TG), and cholesterol by at least $13 \%$ in serum, which was induced by $\mathrm{CCl}_{4}(1 \mathrm{~mL} / \mathrm{kg})$ in mice. In our study, a single subcutaneous dose of $\mathrm{CCl}_{4}(1 \mathrm{~mL} / \mathrm{kg})$ was administered, which led to similar results in liver enzyme activity. Apparently, the hepatoprotective effect of our food supplement is mainly due to the presence of sea buckthorn oil, although the effect of rosehip oils and chokeberry extract cannot be underestimated. If there was an opportunity for a longer recovery of the liver by consuming our dietary supplement, the results would be comparable not only by quality but also by quantity (a decrease in the activity of liver enzymes by at least $50 \%$ ).

Liu et al. [74-77] studied the properties and characteristics of flavonoids derived from rosehip. Antioxidant activity, hepatoprotective effect (liver damage caused by paracetamol or $\mathrm{CCl}_{4}$ ), protective effect in human umbilical vein endothelial cells have been proven in vitro. The mice were divided into seven groups that consumed or did not consume the rosehip flavonoid drug. After 7 days 
of consumption, $\mathrm{CCl}_{4}$ was injected subcutaneously to each mouse from groups 3-7, while groups 1-2 received olive oil. Mice that consumed the rosehip flavonoid drug received less liver damage, which confirmed the hepatoprotective effect of the drug. In the work of Valcheva-Kuzmanova et al. [78], the hepatoprotective effect of chokeberry juice was established (damage to the liver of rats by carbon tetrachloride). The administration of $\mathrm{CCl}_{4}$ increased the activity of AST and ALT in plasma, induced lipid peroxidation. Chokeberry juice reduced the manifestation of damage to the liver of rats and inhibited the increase in the activity of liver enzymes. The authors suggested that the possible mechanisms of this were determined by the fact that the antioxidant properties of the juice reduced $\mathrm{CCl}_{4}$ activity and activated protective mechanisms that restored damaged liver tissue.

In our dietary supplement, the corresponding concentration of chokeberry is slightly lower, and the activity of its biologically active substances is certainly lower, because it is represented by an extract, but in combination with other active ingredients (sea buckthorn and rosehip), a similar positive effect on the liver of mice is observed. Apparently, the method used for obtaining oil from sea buckthorn and rosehip allows one not only to transfer biologically active substances from fruit to oil, but also to enhance the hepatoprotective activity of our biologically active food supplement.

Food products containing sea buckthorn oil are rich in PUFA, model lipid metabolism in the liver, and have pronounced hepatoprotective properties [79-83]. The dosage of our supplement's active components in the diet of laboratory animals was not enough to bring the activity of liver enzymes and antioxidant activity of the blood serum to physiological norms. However, it determines the prospects for the synergistic action of biologically active components of natural fruits, which can become quite an alternative to synthetic substances. Additional research will expand the field of knowledge on this topic.

\section{Conclusions}

The functional properties of sea buckthorn oil, rosehip oil, and chokeberry extract are well known, and the study of a dietary supplement based on them showed that it has no less biologically active characteristics. Our study confirmed the effectiveness of "ESB 1" dietary supplement in reducing ALT and AST levels, reducing liver oxidative processes, and modulating antioxidant protection. The safety of experimental samples of dietary supplements based on sea buckthorn and rosehip oils with added chokeberry extract and their hypocholesterolemic and antioxidant properties have been proven, which suggests using sea buckthorn oil, rosehip oil, and chokeberry extract as a functional formula component of other foods, or the basis of dietary supplements.

The possibility of using the formulated dietary supplement as a nutritional alternative to existing analogues used in medical practice for the treatment and prevention of lipid-carbohydrate metabolism disorders requires additional research. However, the full range of therapeutic and preventive effects, including hepatoprotective, of our dietary supplement based on sea buckthorn oil and rosehip oil with the addition of chokeberry extract have not been fully studied. The possible activity of the components of our dietary supplement in regulating lipid metabolism, reducing oxidative stress and liver inflammation suggests that it has a lipolytic effect when used by people with increased body weight, but this is a theme for future studies.

Author Contributions: Conceived and designed the research-L.T., K.S., I.S.; analyzed and interpreted the data-O.B., L.D., V.P., A.P.; contributed reagents, materials, analysis tools or data-L.T., K.S., I.S.; wrote the paper-O.B., V.P., S.I., A.P. All authors have read and agreed to the published version of the manuscript.

Funding: This research was funded by Ministry of Science and Higher Education of the Russian Federation, grant number 075-15-2019-1383 and grant number FZSR 2020-0006.

Conflicts of Interest: The authors declare no conflict of interest. 


\section{References}

1. Barrea, L.; Annunziata, G.; Muscogiuri, G.; Laudisio, D.; Somma, C.D.; Maisto, M.; Tenore, G.C.; Colao, A.; Savastano, S. Trimethylamine N-oxide, Mediterranean diet, and nutrition in healthy, normal-weight adults: Also a matter of sex? Nutrition 2019, 62, 7-17. [CrossRef] [PubMed]

2. Bolori, P.; Setaysh, L.; Rasaei, N.; Jarrahi, F.; Yekaninejad, M.; Mirzaei, K. Adherence to a healthy plant diet may reduce inflammatory factors in obese and overweight women-a cross-sectional study. Diabetes Metab. Syndr. 2019, 13, 2795-2802. [CrossRef] [PubMed]

3. Kovell, L.C.; Yeung, E.H.; Miller, E.R., III; Appel, L.J.; Christenson, R.H.; Rebuck, H.; Schulman, S.P.; Juraschek, S.P. Healthy diet reduces markers of cardiac injury and inflammation regardless of macronutrients: Results from the OmniHeart trial. Int. J. Cardiol. 2020, 299, 282-288. [CrossRef] [PubMed]

4. Eccleston, C.; Baoru, Y.; Tahvonen, R.; Kallio, H.; Rimbach, G.H.; Minihane, A.M. Effects of an antioxidant-rich juice (sea buckthorn) on risk factors for coronary heart disease in humans. J. Nutr. Biochem. 2002, 13, 346-354. [CrossRef]

5. Shahidi, F.; Ambigaipalan, P. Phenolics and polyphenolics in foods, beverages and spices: Antioxidant activity and health effects-A review. J. Funct. Foods 2015, 18, 820-897. [CrossRef]

6. Mark, R.; Lyua, X.; Lee, J.J.L.; Parra-Saldívar, R.; Chen, W.N. Sustainable production of natural phenolics for functional food applications. J. Funct. Food 2019, 57, 233-254. [CrossRef]

7. Baboota, R.K.; Bishnoi, M.; Ambalam, P.; Kondepudi, K.K.; Sarma, S.M.; Boparai, R.K.; Podili, K. Functional food ingredients for the management of obesity and associated co-morbidities-A review. J. Funct. Foods 2013, 5, 997-1012. [CrossRef]

8. Kumar, S.; Pandey, A.K. Chemistry and biological activities of flavonoids: An overview. Sci. World J. 2013, 2013, 162750. [CrossRef]

9. Basli, A.; Belkacem, N.; Amrani, I. Health benefits of phenolic compounds against cancers. In Phenolic Compounds-Biological Activity; Soto-Hernandez, M., Palma-Tenango, M., Garcia-Mateos, R., Eds.; InTech: Rijeka, Croatia, 2017; Chapter 10. [CrossRef]

10. Wang, D.D. Dietary n-6 polyunsaturated fatty acids and cardiovascular disease: Epidemiologic evidence. Prostaglandins Leukot. Essent. Fatty Acids 2015, 135, 5-9. [CrossRef]

11. Mollenhauer, M.; Mehrkens, D.; Rudolph, V. Nitrated fatty acids in cardiovascular diseases. Nitric Oxide 2018, 78, 146-153. [CrossRef]

12. Sanches-Silva, A.; Albuquerque, T.G.; Finglas, P.; Ribeiro, T.; Valente, A.; Vasilopoulou, E.; Trichopoulou, A.; Alexieva, I.; Boyko, N.; Costea, C.-E.; et al. Carotenoids, vitamins (A, B2, C and E) and total folate of traditional foods from Black Sea Area countries. J. Sci. Food Agric. 2013, 93, 3545-3557. [CrossRef] [PubMed]

13. Andrade, M.A.; Lim, V.; Silva, A.S.; Vilarinho, F.; Castilho, M.C.; Khwaldia, K.; Ramos, F. Pomegranate and grape by-products and their active compounds: Are they a valuable source for food applications? Trends Food Sci. Technol. 2019, 86, 68-84. [CrossRef]

14. Babich, O.; Dyshlyuk, L.; Prosekov, A.; Ivanova, S.; Pavsky, V.; Chaplygina, T. The effect of postharvest ultraviolet irradiation on the content of antioxidant compounds and the activity of antioxidant enzymes in tomato. Heliyon 2020, 6, e03288. [CrossRef]

15. Mori, T.A. Marine OMEGA-3 fatty acids in the prevention of cardiovascular disease. Fitoterapia 2017, 123, 51-58. [CrossRef] [PubMed]

16. Koyama, T.; Taka, A.; Togashi, H. Effects of a herbal medicine, Hippophae rhamnoides, on cardiovascular functions and coronary microvessels in the spontaneously hypertensive stroke-prone rat. Clin. Hemorheol. Microcirc. 2009, 41, 17-26. [CrossRef]

17. Larmo, P.S.; Yang, B.; Hurme, S.A.; Alin, J.A.; Kallio, H.P.; Salminen, E.K.; Tahvonen, R.L. Effect of a low dose of sea buckthorn berries on circulating concentrations of cholesterol, triacylglycerols, and flavonoids in healthy adults. Eur. J. Nutr. 2009, 48, 277-282. [CrossRef]

18. Olas, B. The beneficial health aspects of sea buckthorn (Elaeagnus rhamnoides (L.) A. Nelson) oil. J. Ethnopharmacol. 2018, 213, 183-190. [CrossRef]

19. Saggu, S.; Divekar, H.M.; Gupta, V.; Sawhney, R.C.; Banerjee, P.K.; Kumar, R. Adaptogenic and safety evaluation of sea buckthorn (Hippophae rhamnoides) leaf extract: A dose dependent study. Food Chem. Toxicol. 2007, 45, 609-617. [CrossRef] 
20. Upadhyay, N.K.; Kumar, R.; Mandotra, S.K.; Meena, R.N.; Siddiqui, M.S.; Sawhney, R.C.; Gupta, A. Safety and healing efficacy of sea buckthorn (Hippophae rhamnoides L.) seed oil on burn wounds in rats. Food Chem. Toxicol. 2009, 47, 1146-1153. [CrossRef]

21. Tulsawani, R. Ninety day repeated gavage administration of Hippophae rhamnoides extract in rats. Food Chem. Toxicol. 2010, 48, 2483-2489. [CrossRef]

22. Xu, Y.-J.; Kaur, M.; Dhillon, R.S.; Tappia, P.S.; Dhalla, N.S. Health benefits of sea buckthorn for the prevention of cardiovascular diseases. J. Funct. Foods 2011, 3, 2-12. [CrossRef]

23. Ding, J.; Ruan, C.J.; Guan, Y.; Sham, J.Y.; Li, H.; Bao, Y.H. Characterization and identification of ISSR markers associated with oil content in sea buckthorn berries. Genet. Mol. Res. 2016, 15, gmr.15038278. [CrossRef] [PubMed]

24. Christaki, E. Hippophae rhamnoides L. (Sea buckthorn): A potential source of nutraceuticals. Food Public Health 2012, 2, 69-72. [CrossRef]

25. Zeb, A. Anticarcinogenic potential of lipids from hippophae-Evidence from the recent literature. Asian Pac. J. Cancer Prev. 2006, 7, 32-35.

26. Kumar, R.; Kumar, G.P.; Chaurasia, O.P.; Singh, S. Phytochemical and pharmacological profile of seabuckthorn oil: A review. Res. J. Med. Plant 2011, 5, 491-499. [CrossRef]

27. Yang, B.; Kalimo, K.O.; Tahvonen, R.L.; Mattil, L.M.; Katajisto, J.K.; Kallio, H.P. Effect of dietary supplementation with sea buckthorn (Hippophaë rhamnoides) seed and pulp oils on the fatty acid composition of skin glycerophospholipids of patients with atopic dermatitis. J. Nutr. Biochem. 2000, 11, 338-340. [CrossRef]

28. Teleszko, M.; Wojdylo, A.; Rudzinska, M.; Oszmiański, J.; Golis, T. Analysis of lipophilic and hydrophilic bioactive compounds content in sea buckthorn (Hippophae rhamnoids L.) berries. J. Agric. Food Chem. 2015, 63, 4120-4129. [CrossRef]

29. Wang, Y.; Zhao, L.; Huo, Y.; Zhou, F.; Wu, W.; Lu, F.; Yang, X.; Guo, X.; Chen, P.; Deng, Q.; et al. Protective effect of proanthocyanidins from sea buckthorn (Hippophae rhamnoides L.) seed against visible light-induced retinal degeneration in vivo. Nutrients 2016, 8, 245. [CrossRef]

30. Olas, B. Sea buckthorn as a source of important bioactive compounds in cardiovascular diseases. Food Chem. Toxicol. 2016, 97, 199-204. [CrossRef]

31. Barros, L.; Carvalho, A.M.; Morais, J.S.; Ferreira, I.C.F.R. Strawberry tree, blackthorn and rose fruits: Detailed characterization in nutrients and phytochemicals with antioxidant properties. Food Chem. 2010, 120, 247-254. [CrossRef]

32. Demir, N.; Yıldız, O.; Alpaslan, M.; Hayaloglu, A.A. Evaluation of volatiles, phenolic compounds and antioxidant activities of rosehip (Rosa L.) fruits in Turkey. LWT-Food Sci. Technol. 2014, 57, 126-133. [CrossRef]

33. Salgın, U.; Salgın, S.; Ekici, D.D.; Uludal, G. Oil recovery in rosehip seeds from food plant waste products using supercritical $\mathrm{CO}_{2}$ extraction. J. Supercrit. Fluids 2016, 118, 194-202. [CrossRef]

34. Grajer, M.; Prescha, A.; Korzonek, K.; Wojakowska, A.; Dziadas, M.; Kulma, A.; Grajeta, H. Characteristics of rose hip (Rosa canina L.) cold pressed oil and its oxidative stability studied by the differential scanning calorimetry method. Food Chem. 2015, 188, 459-466. [CrossRef] [PubMed]

35. Nadpal, J.D.; Lesjak, M.M.; Šibul, F.S.; Analkov, G.T.; Letojevil-Simin, D.D.; Mimica-Dukil, N.M.; Beara, I.N. Comparative study of biological activities and phytochemical composition of two rose hips and their preserves: Rosa canina L. and Rosa arvensis Huds. Food Chem. 2016, 192, 907-914. [CrossRef] [PubMed]

36. Kharazmi, A. Laboratory and preclinical studies on the anti-inflammatory and anti-oxidant properties of rosehip powder-identification and characterization of the active component GOPO ${ }^{\circledR}$. Osteoarthr. Cartil. 2008, 16, S5-S7. [CrossRef]

37. Bhave, A.; Schulzova, V.; Chmelarova, H.; Mrnka, L.; Hajslova, J. Assessment of rosehips based on the content of their biologically active compounds. J. Food Drug Anal. 2017, 25, 681-690. [CrossRef]

38. Kohlmeier, L.; Kark, J.D.; Gomez-Gracia, E.; Martin, B.C.; Steck, S.E.; Kardinaal, A.F.; Ringstad, J.; Thamm, M.; Masaev, V.; Riemersma, R.; et al. Lycopene and myocardial infraction risk in the EURAMIC study. Am. J. Epidemiol. 1997, 146, 618-626. [CrossRef]

39. Giovannucci, E. Tomatoes, tomato-based products, lycopene, and cancer: Review of the epidemiologic literature. J. Natl. Cancer Inst. 1999, 91, 317-331. [CrossRef]

40. Böhm, V.; Fröhlich, K.; Bitsch, R. Rosehip_A “new" source of lycopene? Mol. Aspects Med. 2003, 24, 385-389. [CrossRef] 
41. Alam, P.; Raka, M.A.; Khan, S.; Sarker, J.; Ahmed, N.; DevNath, P.; Hasan, N.; Mohib, M.d.M.; Tisha, A.; Sagor, M.d.A.T. A clinical review of the effectiveness of tomato (Solanum lycopersicum) against cardiovascular dysfunction and related metabolic syndrome. J. Herb. Med. 2019, 16, 100235. [CrossRef]

42. Babich, O.; Dyshlyuk, L.; Sukhikh, S.; Prosekov, A.; Ivanova, S.; Pavsky, V.; Chaplygina, T.; Kriger, O. Effects of Biopreservatives Combined with Modified Atmosphere Packaging on the Quality of Apples and Tomatoes. Pol. J. Food Nutr. Sci. 2019, 69, 110564. [CrossRef]

43. Chrubasik, C.; Roufogalis, B.D.; Müller-Ladner, U.; Chrubasik, S. A systematic review on the Rosa canina effect and efficacy profiles. Phytother. Res. 2008, 22, 725-733. [CrossRef] [PubMed]

44. Wenzig, E.M.; Widowitz, U.; Kunert, O.; Churbasik, S.; Bucar, F.; Knauder, E.; Bauer, R. Phytochemical composition and in vivo pharmacological activity of two rose hip (Rosa canina L.) preparations. Phytomedicine 2008, 15, 826-835. [CrossRef]

45. Ege, I.; Sánchez-Bel, P.; Romojaro, F.; Pretel, M.T. Six edible wild fruits as potential antioxidant additives or nutritional supplements. Plant. Foods Hum. Nutr. 2010, 65, 121-129. [CrossRef] [PubMed]

46. Barros, L.; Carvalho, A.M.; Ferreira, I.C.F.R. Exotic fruits as a source of important phytochemicals: Improving the traditional use of Rosa canina fruits in Portugal. Food Res. Int. 2011, 44, 2233-2236. [CrossRef]

47. Tumbas, V.T.; Lanadovil-Brunet, J.M.; Letojevil-Simin, D.D.; Letkovil, G.S.; Lilas, S.; Gille, L. Effect of rosehip (Rosa canina L.) phytochemicals on stable free radicals and human cancer cells. J. Food Compost. Anal. 2012, 92, 1273-1281. [CrossRef]

48. Guimaraes, R.; Barros, L.; Calhelha, R.C.; Carvalho, A.M.; Queiroz, M.J.R.P.; Ferreira, I.C.F.R. Bioactivity of different enriched phenolic extracts of wild fruits from northeastern Portugal: A comparative study. Plant Foods Hum. Nutr. 2014, 69, 37-42. [CrossRef]

49. Oszmiański, J.; Lachowicz, S. Effect of the production of dried fruits and juice from chokeberry (Aronia melanocarpa L.) on the content and antioxidative activity of bioactive compounds. Molecules 2016, 21, 1098. [CrossRef]

50. Tolić, M.T.; Krbavčić, I.P.; Vujević, P.; Milinović, B.; Jurčević, I.L.; Vahčić, N. Effects of weather conditions on phenolic content and antioxidant capacity in juice of chokeberries (Aronia melanocarpa L.). Polish J. Food Nutr. Sci. 2017, 67, 67-74. [CrossRef]

51. Chrubasik, C.; Li, G.; Chrubasik, S. The clinical effectiveness of chokeberry: A systematic review. Phytother. Res. 2010, 24, 1107-1114. [CrossRef]

52. Sidor, A.; Drożdżyńska, A.; Gramza-Michałowska, A. Black chokeberry (Aronia melanocarpa) and its products as potential health-promoting factors-An overview. Trends Food Sci. Technol. 2019, 89, 45-60. [CrossRef]

53. Babich, O.; Prosekov, A.; Zaushincena, A.; Sukhikh, A.; Dyshlyuk, L.; Ivanova, S. Identification and quantification of phenolic compounds of Western Siberia Astragalus danicus in different regions. Heliyon 2019, 5, e02245. [CrossRef]

54. Madić, V.; Stojanović-Radić, Z.; Jušković, M.; Jugović, D.; Žabar Popović, A.; Vasiljević, P. Genotoxic and antigenotoxic potential of herbal mixture and five medicinal plants used in ethnopharmacology. S. Afr. J. Bot. 2019, 125, 290-297. [CrossRef]

55. Dyshlyuk, L.; Babich, O.; Prosekov, A.; Ivanova, S.; Pavsky, V.; Yang, Y. In vivo study of medical and biological properties of functional bakery products with the addition of pumpkin flour. Bioact. Carbohydr. Diet. Fibre 2017, 12, 20-24. [CrossRef]

56. Babich, O.; Dyshlyuk, L.; Noskova, S.; Sukhikh, S.; Prosekov, A.; Ivanova, S.; Pavsky, V. In vivo study of the potential of the carbohydrate-mineral complex from pine nut shells as an ingredient of functional food products. Bioact. Carbohydr. Diet. Fibre 2019, 18, 100185. [CrossRef]

57. Allain, C.C.; Poon, L.S.; Chan, C.S.; Richmond, W.; Fu, P.C. Enzymatic determination of total serum cholesterol. Clin. Chem. 1974, 20, 470-475. [CrossRef]

58. Ohkawa, H.; Ohishi, N.; Yagi, K. Assay for lipid peroxides in animal tissues by thiobarbituric acid reaction. Anal. Biochem. 1979, 95, 351-358. [CrossRef]

59. Yagi, K. Lipid Peroxides and Human Diseases. Chem. Phys. Lipids 1987, 45, 337-351. [CrossRef]

60. Cao, G.; Sofic, E.; Prior, R.L. Antioxidant and prooxidant behavior of flavonoids: Structure-activity relation ships. Free Radic. Biol. Med. 1997, 22, 749-760. [CrossRef]

61. Tereshchuk, L.V.; Starovoitova, K.V. Aspects of production of functional emulsion foods. Foods Raw Mater. 2013, 1, 67-75. [CrossRef] 
62. Ivanova, S.A.; Pavskii, V.A. Stochastic modeling of protein solution foaming process. Theor. Found. Chem. Eng. 2014, 48, 848-854. [CrossRef]

63. Dyshlyuk, L.S.; Sukhikh, S.A.; Ivanova, S.A.; Smirnova, I.A.; Subbotina, M.A.; Pozdnyakova, A.V.; Neverov, E.N.; Garmashov, S.Y. Prospects for using pine nut products in the dairy industry. Food Raw Mater. 2018, 6, 264-280. [CrossRef]

64. Prosekov, A.; Babich, O.; Kriger, O.; Ivanova, S.; Pavsky, V.; Sukhikh, S.; Yang, Y.; Kashirskih, E. Functional properties of the enzyme-modified protein from oat bran. Food Biosci. 2018, 24, 46-49. [CrossRef]

65. Terechuk, L.; Starovoytova, K.; Ivanova, S.; Sergeeva, I. Obtaining Functional Products from Sea Buckthorn Berries. In Proceedings of the 2nd International Conference on Education Science and Social Development, 2019 (ESSD 2019), Changsha, China, 20-21 July 2019. [CrossRef]

66. Babich, O.O.; Milent'eva, I.S.; Ivanova, S.A.; Pavsky, V.A.; Kashirskikh, E.V.; Yang, Y. The potential of pine nut as a component of sport nutrition. Foods Raw Mater. 2017, 5, 170-177. [CrossRef]

67. Prosekov, A.Y.; Dyshlyuk, L.S.; Milent'eva, I.S.; Pavsky, V.A.; Ivanova, S.A.; Garmashov, S.Y. Study of the biofunctional properties of cedar pine oil with the use of testing cultures. Food Raw Mater. 2018, 6, 136-143. [CrossRef]

68. OECD Guidelines for Testing of Chemicals; Organisation for Economic Co-operation and Development: Paris, France, 1981; Available online: http://www.oecd.org/department/0,3355,en_2649_34377_1_1_1_1_1,00.html (accessed on 24 December 2018).

69. Istrati, D.; Lacatusu, I.; Bordei, N.; Badea, G.; Oprea, O.; Stefan, L.M.; Stan, R.; Badea, N.; Meghea, A. Phyto-mediated nanostructured carriers based on dual vegetable actives involved in the prevention of cellular damage. Mater. Sci. Eng. C 2016, 64, 249-259. [CrossRef]

70. Lavinia, S.; Gabi, D.; Drinceanu, D.; Daniela, D.; Stef, D.; Daniela, M.; Julean, C.; Romana, T.; Corionovoschi, N. The effect of medicinal plants and plant extracted oils on broiler duodenum morphology and immunological profile. Rom. Biotechnol. Let. 2009, 14, 4606-4614.

71. Patel, S. Rose hip as an underutilized functional food: Evidence-based review. Trends Food Sci. Technol. 2017, 63, 29-38. [CrossRef]

72. Basu, M.; Prasad, R.; Jayamurthy, P.; Pal, K.; Arumughan, C.; Sawhney, R.C. Anti-atherogenic effects of sea buckthorn (Hippophaea rhamnoides) seed oil. Phytomedicine 2007, 14, 770-777. [CrossRef]

73. Hsu, Y.W.; Tsai, C.F.; Chen, W.K.; Lu, F.J. Protective effects of seabuckthorn (Hippophae rhamnoides L.) seed oil against carbon tertrachloride-induced hepatotoxicity in mice. Food Chem. Toxicol. 2009, 47, 2281-2288. [CrossRef]

74. Liu, Y.T.; Lu, B.N.; Xu, L.N.; Yin, L.H.; Wang, X.N.; Peng, J.Y.; Liu, K.X. The antioxidant activity and hypolipidemic activity of the total flavonoids from the fruit of Rosa laevigata Michx. Nat. Sci. 2010, 2, 175-183. [CrossRef]

75. Jia, Y.; Ji, L.; Zhang, S.; Xu, L.; Yin, L.H.; Li, L.; Zhao, Y.; Peng, J. Total flavonoids from Rosa Laevigata Michx fruit attenuates hydrogen peroxide induced injury in human umbilical vein endothelial cells. Food Chem. Toxicol. 2012, 50, 3133-3141. [CrossRef] [PubMed]

76. Zhang, S.; Lu, B.; Han, X.; Xu, L.; Qi, Y.; Yin, L.; Xu, Y.; Zhao, Y.; Liu, K.; Penga, J. Protection of the flavonoid fraction from Rosa laevigata Michx fruit against carbon tetrachloride-induced acute liver injury in mice. Food Chem. Toxicol. 2013, 55, 60-69. [CrossRef]

77. Denev, P.; Číž, M.; Kratchanova, M.; Blazheva, D. Black chokeberry (Aronia melanocarpa) polyphenols reveal different antioxidant, antimicrobial and neutrophil-modulating activities. Food Chem. 2019, 284, 101-117. [CrossRef]

78. Valcheva-Kuzmanova, S.; Borisova, P.; Galunska, B.; Krasnaliev, I.; Belcheva, A. Hepatoprotective effect of the natural fruit juice from Aronia melanocarpa on carbon tetrachloride-induced acute liver damage in rats. Exp. Toxicol. Pathol. 2004, 56, 195-201. [CrossRef]

79. Mardones, M.; Valenzuela, R.; Romanque, P.; Covarrubias, N.; Anghileri, F.; Fernández, V.; Videla, L.A.; Tapia, G. Prevention of liver ischemia reperfusion injury by a combined thyroid hormone and fish oil protocol. J. Nutr. Biochem. 2012, 23, 1113-1120. [CrossRef] [PubMed]

80. Valenzuela, R.; Illesca, P.; Echeverría, F.; Espinosa, A.; Rincón-Cervera, M.Á.; Ortiz, M.; Hernandez-Rodas, M.C.; Valenzuela, A.; Videla, L.A. Molecular adaptations underlying the beneficial effects of hydroxytyrosol in the pathogenic alterations induced by a high-fat diet in mouse liver: PPAR- $\alpha$ and Nrf2 activation, and NF-kB down-regulation. Food Funct. 2017, 8, 1526-1537. [CrossRef] 
81. Hernández-Rodas, M.C.; Valenzuela, R.; Echeverría, F.; Rincón-Cervera, M.Á.; Espinosa, A.; Illesca, P.; Muñoz, P.; Corbari, A.; Romero, N.; Gonzalez-Mañan, D.; et al. Supplementation with Docosahexaenoic Acid and Extra Virgin Olive Oil Prevents Liver Steatosis Induced by a High-Fat Diet in Mice through PPAR- $\alpha$ and Nrf2 Upregulation with Concomitant SREBP-1c and NF-kB Downregulation. Mol. Nutr. Food Res. 2017, 61, 1700479. [CrossRef]

82. Illesca, P.; Valenzuela, R.; Espinosa, A.; Echeverría, F.; Soto-Alarcon, S.; Ortiz, M.; Videla, L.A. Hydroxytyrosol supplementation ameliorates the metabolic disturbances in white adipose tissue from mice fed a high-fat diet through recovery of transcription factors Nrf2, SREBP-1c, PPAR- $\gamma$ and NF-kB. Biomed. Pharmacother. 2019, 109, 2472-2481. [CrossRef]

83. Soto-Alarcón, S.A.; Ortiz, M.; Orellana, P.; Echeverría, F.; Bustamante, A.; Espinosa, A.; Illesca, P.; Gonzalez-Mañán, D.; Valenzuela, R.; Videla, L.A. Docosahexaenoic acid and hydroxytyrosol co-administration fully prevents liver steatosis and related parameters in mice subjected to high-fat diet: A molecular approach. BioFactors 2019, 45, 930-943. [CrossRef]

(C) 2020 by the authors. Licensee MDPI, Basel, Switzerland. This article is an open access article distributed under the terms and conditions of the Creative Commons Attribution (CC BY) license (http://creativecommons.org/licenses/by/4.0/). 